\title{
molecules
}

ISSN 1420-3049

www.mdpi.com/journal/molecules

Article

\section{Comparison of Physicochemical Properties and Immunomodulatory Activity of Polysaccharides from Fresh and Dried Litchi Pulp}

Fei Huang ${ }^{1,2}$, Ruifen Zhang ${ }^{2}$, Yang Yi ${ }^{3}$, Xiaojun Tang ${ }^{2}$, Mingwei Zhang ${ }^{2, *}$, Dongxiao Su ${ }^{1,2}$, Yuanyuan Deng ${ }^{2}$ and Zhencheng Wei ${ }^{2}$

1 Department of Food Science and Technology, Huazhong Agricultural University, Wuhan 430070, China

2 Sericultural and Agri-food Research Institute, Guangdong Academy of Agricultural Sciences, Guangzhou 510610, China

3 College of Food Science \& Engineering, Wuhan Polytechnic University, Wuhan 430023, China

* Author to whom correspondence should be addressed; E-Mail: mwzhh@vip.tom.com; Tel.: +86-20-8723-7865; Fax: +86-20-8723-6354.

Received: 17 February 2014; in revised form: 20 March 2014 / Accepted: 21 March 2014 / Published: 31 March 2014

Abstract: Drying is commonly used for preservation and processing of litchi. However, its polysaccharide structure may be altered by the drying process, resulting in biological activity changes. Polysaccharides from fresh and dried litchi pulp (denoted as LPF and LPD, respectively) were isolated, investigated by GC-MS, GPC and UV/IR spectrum analysis and their antitumor and immunomodulatory activities were evaluated in vitro. LPD, the molecular weight of which was lower than that of LPF, contained more protein, uronic acid, arabinose, galactose and xylose. Compared with LPF, LPD exhibited a higher inhibitory effect on the proliferation of HepG2, Hela and A549 cells from 50-750 $\mu \mathrm{g} / \mathrm{mL}$. LPD was also a better stimulator of spleen lymphocyte proliferation, NK cells cytotoxicity and macrophage phagocytosis from $50-400 \mu \mathrm{g} / \mathrm{mL}$. In summary, drying could change the physicochemical properties and enhance the bioactivity of polysaccharides from litchi pulp. This finding is supported by the fact that dried litchi pulps are used in Traditional Chinese Medicine.

Keywords: litchi; drying; polysaccharides; anti-tumor activity; immunomodulatory activity 


\section{Introduction}

Litchi (Litchi chinensis Sonn.), originating from China, is widely planted in warm climates around the World. Because of its attractive appearance and delicious flavor, litchi is becoming increasingly popular. Besides providing sensory satisfaction, litchi fruit extracts have been reported to have antioxidant properties [1,2], proinflammatory effects [3], anticancer activity [4], anti-apoptotic activities [5] and immune-stimulating activities [6]. Many bioactive compounds have been identified from litchi pulp, including polysaccharides which exhibit antioxidant activities [7].

Litchi is a seasonal and highly perishable fruit that is commonly dried for long term storage and further processing. However, the drying process has been shown to have a significant effect on the physicochemical properties and characteristic components of the material. A previous study showed that drying changed the content of dietary fiber in orange by-products [8], as well as the content of total phenolics, flavonoids and lycopene in tomatoes [9]. Furthermore, drying may cause irreversible modifications to the chemical composition and structure of polysaccharides. For example, a sun-drying process caused the modification of monosaccharide composition and FT-IR characteristics of polysaccharides from pear pulp [10]. The molecular size distribution and proportions of $(1 \rightarrow 3,6)$-linked galactose residues of pectin polysaccharides from Japanese persimmon fruit were also changed during the sun-drying process [11].

It is well known that the bioactivities of native polysaccharides are closely related to their chemical composition and structure. The crude polysaccharides from the dried fruit body of Lentinus polychrous Lév contained more proteins, total polysaccharides and reducing sugar and showed stronger antioxidant activity and cytotoxicity against MCF-7 tumor cells [12] than those from fresh fruit bodies. Furthermore, thermal drying could change the structure of mushroom polysaccharides and result in aggregation of polysaccharides due to removal of the hydration layer. The aggregated polysaccharides were larger, but had lower antioxidant activity compared with polysaccharides from freeze dried material [13]. Although the structure and activity of litchi polysaccharides have been reported in previous research [1,7,14,15], little is known about the effects of drying on the polysaccharides in litchi. Therefore, the polysaccharides from fresh and hot-air dried litchi pulp were analyzed in the present study. The objectives were: (1) to reveal the differences in the physicochemical properties of the polysaccharides from fresh and hot-air dried litchi pulp; (2) to compare their antitumor and immunomodulatory activity in vitro; (3) to elucidate the relationships between their structure and bioactivity.

\section{Results and Discussion}

\subsection{Preliminary Characterization of Litchi Polysaccharides}

\subsubsection{The Chemical Compositions of Litchi Polysaccharides}

Two hundred grams fresh pulp and $50 \mathrm{~g}$ dried pulp of litchi were used to obtain litchi polysaccharides. The yield of polysaccharides was $1.15 \%$ from fresh litchi pulp and that from dried litchi pulp was $3.58 \%$. The amount of neutral sugar, uronic acid and protein, as well as molecular weight distribution and monosaccharide composition of LPF and LPD are summarized in Table 1. 
Obviously, LPD contained more uronic acid and binding protein than LPF $(p<0.05)$. The result was consistent with Thetsrimuang's report in which the protein content of polysaccharides from dried Lentinus polychrous Lév was significantly higher than in fresh ones [12]. The difference in protein content of LPF and LPD could be due to thermal effects which could induce conformational changes in the polysaccharides and proteins that may result in the formation of protein-polysaccharide complexes by electrostatic interactions [16], since free but not binding protein could be removed from the polysaccharides by the Sevag method [17]. Moreover, Asgar reported the uronic acid content in polysaccharides from Japanese persimmon fruit increased after sun-drying compared with fresh material [11], which was consistent with our results.

Table 1. The chemical compositions of litchi polysaccharides LPF and LPD.

\begin{tabular}{ccc}
\hline Samples & LPF & LPD \\
\hline Neutral sugar (W\%) & $66.85 \pm 1.12$ & $65.73 \pm 1.76$ \\
Uronic acid (W\%) & $2.09 \pm 0.48$ & $4.72 \pm 0.27 *$ \\
Protein(W\%) & $3.94 \pm 0.16$ & $6.48 \pm 0.24 *$ \\
Molecular weight (Da) & 970085 & $370365 ; 8207$ \\
Monosaccharide composition (\%) & & \\
Rhamnose & 0.31 & 1.86 \\
Arabinose & 5.44 & 17.62 \\
Xylose & 0.71 & 3.21 \\
Mannose & 15.18 & 10.56 \\
Glucose & 66.1 & 20.82 \\
Galactose & 11.58 & 41.18 \\
\hline
\end{tabular}

LPF had a large molecular weight $\left(\mathrm{M}_{\mathrm{w}}\right)$ of 970,085 Da, while LPD was observed to be composed of two components with relatively small molecular weights (Table 1). The results were similar to the change of molecular weight of polysaccharides from Inonotus obliquus which decreased with thermal treatment [18]. It was inferred that the cleavage of the polysaccharides chain accounted for the decrease of $\mathrm{M}_{\mathrm{w}}$ value upon thermal treatment.

LPF and LPD had the same monosaccharide composition, but their monosaccharide molar ratios had apparent differences. Compared with LPF, the molar ratio of glucose in LPD exhibited a $45.28 \%$ decrease, while galactose and arabinose were increased by $29.6 \%$ and $12.18 \%$, respectively. Mirhosseini et al. reported freeze-drying and spray-drying processes resulted in the significant reduction of glucose, galactose and arabinose in gum polysaccharides while they were increased by an oven drying process [19]. Asgar et al. found the galactose content of pectin polysaccharides decreased while the arabinose content increased with sun-drying [20]. It can be concluded that temperature and method for drying materials are important factors influencing the monosaccharide composition of polysaccharides in them. The differences among our study and others could result from different processing conditions and materials.

The amount of neutral sugar and uronic acid were individually determined by a phenol-sulfuric acid method and an $m$-hydroxydiphenyl method, respectively. The protein content and monosaccharide composition were determined by Bradford's method and a GC-MS method, respectively. The average 
molecular weight of the polysaccharides was determined by gel permeation chromatography (GPC). The values for neutral sugar, uronic acid, and protein are expressed as the mean $\pm \operatorname{SD}(n=3) .{ }^{*} p<0.05$.

\subsubsection{UV and IR Spectra Analysis}

The UV absorptions of LPF and LPD are shown in Figure 1. The absorption of polysaccharides treated with sodium hydroxide was higher than that of the non-treated control at $240 \mathrm{~nm}$ in LPD, but not in LPF, indicating the presence of O-glycosidic bonds in LPD. This may be attributed to the formation of protein-polysaccharide complexes by electrostatic interactions between polysaccharides and proteins with thermal effects [21]. When immersed in a weak alkali solution, the O-glycosidic bonds between serine or threonine and sugars would produce $\alpha$-aminoacrylic acid and $\alpha$-aminobutenoic acid, which results in an increase of absorbance at $240 \mathrm{~nm}$ [22]. The absorbance at $280 \mathrm{~nm}$ in LPD was higher than that in LPF, which indicated the content of protein in LPD was higher than that in LPF, which was consistent with the result obtained from the Bradford determination.

Figure 1. UV spectra of the $\beta$-elimination reactions of the litchi polysaccharides LPF and LPD. A dotted line represents the absorption of polysaccharide treated with sodium hydroxide, and a solid line represents the absorption of non-treated polysaccharide.
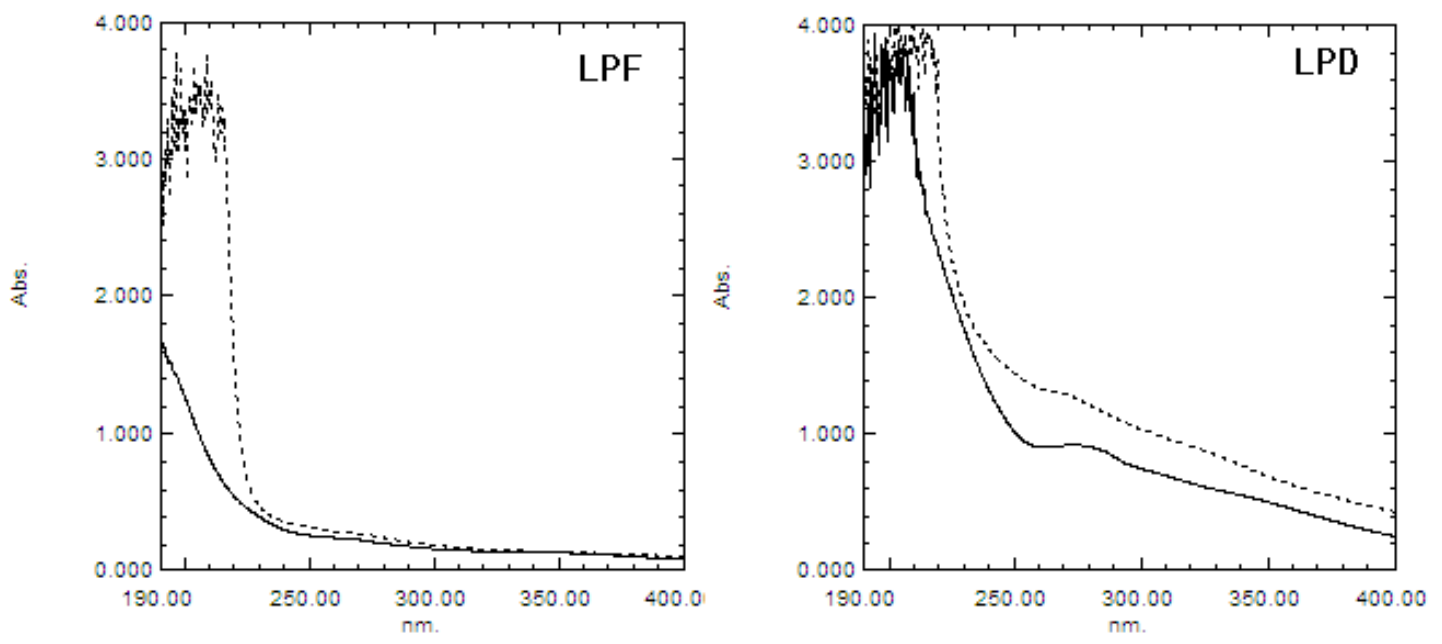

The absorption peaks, functional groups and structural characteristics of LPF and LPD are summarized in Table 2. Both LPF and LPD had hydroxyl groups $\left(3397.4,3405.6 \mathrm{~cm}^{-1}\right)$, alkyl groups (2928.0, 2926.1 $\mathrm{cm}^{-1}$ ) and carboxyl groups $\left(1654.5,1637.6 \mathrm{~cm}^{-1}\right)$, which are characteristic of polysaccharides. In addition, the amino group bands $\left(3397.4,3405.6 ; 1654.5,1637.6 \mathrm{~cm}^{-1}\right)$ indicated the presence of protein in LPF and LPD. However, there were some differences between the spectra of LPF and LPD. LPF lacked the absorption peaks at $1541.4 \mathrm{~cm}^{-1}$ and $1458.8 \mathrm{~cm}^{-1}$ which represented the stretching vibration of $\mathrm{C}=\mathrm{O}$, and bending vibration of $\mathrm{C}-\mathrm{H}$, respectively. Moreover, the absorption peaks at $1156.0,917.9$ and $848.9 \mathrm{~cm}^{-1}$ indicating the ether -C-O-C-, D-glucopyranose ring and $\alpha$-type glycosidic linkage, respectively, only existed in LPF. 
Table 2. FTIR spectra of litchi polysaccharides LPF and LPD.

\begin{tabular}{|c|c|c|c|}
\hline \multicolumn{2}{|c|}{$\operatorname{Absorption}\left(\mathrm{cm}^{-1}\right)^{\text {a }}$} & \multirow{2}{*}{ Functional group $^{b}$} & \multirow{2}{*}{ Structural characteristics } \\
\hline LPF & LPD & & \\
\hline \multirow[t]{2}{*}{3397.4} & 3405.6 & hydroxyl group (-OH) & $\mathrm{O}-\mathrm{H}$ stretching vibration \\
\hline & & amino group $\left(-\mathrm{NH}_{2}\right)$ & $\mathrm{N}-\mathrm{H}$ stretching vibration \\
\hline 2928.0 & 2926.1 & alkyl group $\left(-\mathrm{CH}_{2}-\right)$ & C-H stretching vibration \\
\hline \multirow[t]{4}{*}{1654.5} & 1637.6 & carbonyl group $(-\mathrm{C}=\mathrm{O}$ or $-\mathrm{CHO})$ & $\mathrm{C}=\mathrm{O}$ stretching vibration \\
\hline & & amide group $\left(-\mathrm{NH}_{2}\right.$ or $\left.-\mathrm{COR}\right)$ & $\begin{array}{c}\mathrm{N}-\mathrm{H} \text { bending vibration or } \mathrm{C}=\mathrm{O} \\
\text { stretching vibration }\end{array}$ \\
\hline & & amino group $\left(-\mathrm{NH}_{2}\right)$ & $\mathrm{N}-\mathrm{H}$ bending vibration \\
\hline & & bound water & \\
\hline \multirow[t]{2}{*}{1541.4} & & amino group $\left(-\mathrm{NH}_{2}\right)$ or amide group $\left(-\mathrm{NH}_{2}\right)$ & $\mathrm{N}-\mathrm{H}$ bending vibration \\
\hline & & carbonyl group $(-\mathrm{C}=\mathrm{O})$ & $\mathrm{C}=\mathrm{O}$ stretching vibration \\
\hline 1458.8 & & alkyl group $\left(-\mathrm{CH}_{2}-\right.$ or $\left.-\mathrm{CH}_{3}\right)$ & $\mathrm{C}-\mathrm{H}$ bending vibration \\
\hline 1420.0 & 1420.8 & carboxyl group (-COOH) & C-O stretching vibration \\
\hline 1364.0 & 1375.8 & carboxyl group $(-\mathrm{COOH})$ & $\begin{array}{c}\mathrm{C}=\mathrm{O} \text { symmetrical stretching } \\
\text { vibration }\end{array}$ \\
\hline 1270.8 & 1275.1 & carboxyl group (-COOH) & O-H bending vibration \\
\hline 1156.0 & & ether (-C-O-C-) & C-O stretching vibration \\
\hline 1017.0 & 1074.7 & hydroxyl group (-OH) & $\mathrm{O}-\mathrm{H}$ bending vibration \\
\hline 917.9 & & D-glucopyranose ring & Antisymmetrical ring vibration \\
\hline 848.9 & & $\alpha$-type glycosidic linkage & $\mathrm{C}-\mathrm{H}$ bending vibration \\
\hline 764.8 & 777.4 & D-glucopyranose ring & symmetrical ring vibration \\
\hline
\end{tabular}

${ }^{a}$ The FTIR spectra of litchi polysaccharides LPF and LPD were determined using a Fourier-transform infrared spectrophotometer over the frequency range of $4,000-400 \mathrm{~cm}^{-1} ;{ }^{\mathrm{b}}$ The functional group and structural characteristics were obtained from [22].

\subsection{In Vitro Inhibition Effects of Tumor Cell Proliferation of Litchi Polysaccharides}

The inhibitory activities of litchi polysaccharides on the proliferation of HepG2, Hela, and A549 cells are shown in Figure 2. No cytotoxicity was observed toward three tumor cell lines treated at concentrations $\leq 1000 \mu \mathrm{g} / \mathrm{mL}$ of LPF and LPD (data not shown). Both LPF and LPD inhibited the proliferation of three tumor cell lines in a concentration dependent manner at the tested concentrations. HepG2 cells were inhibited from $-0.57 \%$ to $24.12 \%$ by LPF, while the percent inhibition for LPD ranged from $3.11 \%$ at $50 \mu \mathrm{g} / \mathrm{mL}$ to $41.37 \%$ at $750 \mu \mathrm{g} / \mathrm{mL}$ (Figure $2 \mathrm{a}$ ). LPD showed a significantly higher inhibitory effect on the proliferation of HepG2 cells than LPF at the tested concentrations, except $200 \mu \mathrm{g} / \mathrm{mL}(p<0.05)$. Similarly, the proliferation of Hela cells were inhibited $4.61 \%-28.04 \%$ and $5.17 \%-35.65 \%$ by LPF and LPD, respectively, in the dose range of 50-750 $\mu \mathrm{g} / \mathrm{mL}$ (Figure $2 \mathrm{~b}$ ). The differences between LPF and LPD in their inhibition of Hela cells growth were exhibited at high concentrations $(450,600$ and $750 \mu \mathrm{g} / \mathrm{mL})(p<0.05)$. Moreover, the growth of A549 cells decreased $2.59 \%-30.07 \%$ and $2.56 \%-27.17 \%$ by the incubation of LPF and LPD at the tested concentrations, respectively (Figure 2c). The differences between LPF and LPD in their inhibition of A549 cells growth were exhibited only at $450 \mu \mathrm{g} / \mathrm{mL}(p<0.05)$. 
Figure 2. The inhibition of proliferation of cancerous cells by the litchi polysaccharides LPF and LPD. HepG2 (a), Hela (b), and A549 (c) cells were incubated at different concentrations $(50,150,300,450,600$ and $750 \mu \mathrm{g} / \mathrm{mL})$. The percent inhibition were assessed by the methylene blue method and expressed as the mean \pm standard deviation $(n=6)$. Bars labeled with different letters represent a statistical difference at $p<0.05$ among different concentrations of the same sample. (*) $0.01<p<0.05$ and (**) $p<0.01$ compared with LPF.

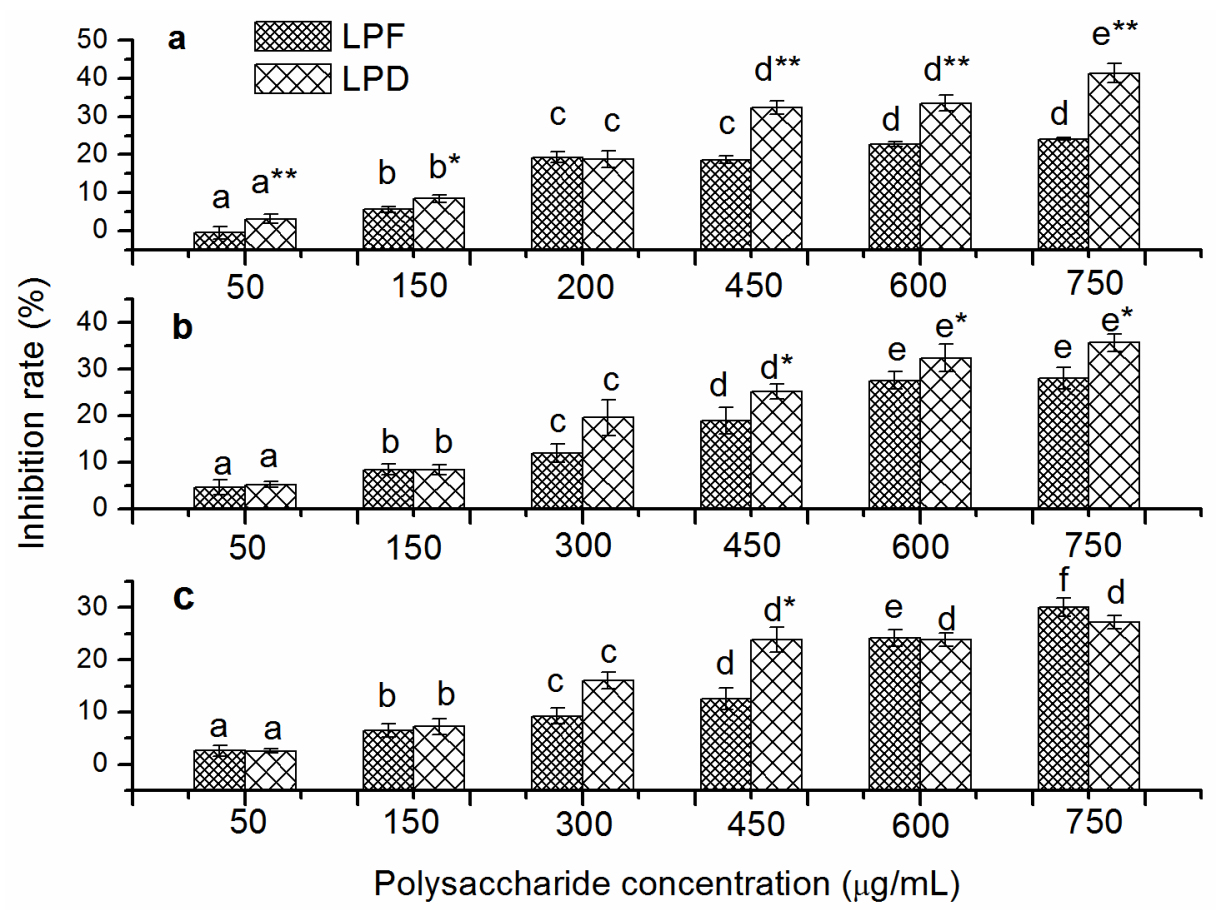

The anti-tumor cell line activity of crude polysaccharides with free protein was also determined. The results showed that polysaccharides without free protein showed better anti-tumor cell line activities whether for LPF or for LPD (data not shown), which implied that the potential active component was the polysaccharides. The bioactivity of polysaccharides is closely related with their chemical composition and structure. LPD, which had higher uronic acid, showed stronger anti-tumor cell line activity in vitro than LPF in this study. It was previously reported that polysaccharides rich in uronic acid exhibited high biological activities because uronic acid residues may alter the properties of polysaccharides and modify their solubility [23,24]. Furthermore, LPD exhibited higher anti-tumor cell line than LPF may due to its molecular weight and monosaccharide composition. Ouchi et al. reported that galactomannan was specifically recognized by a galactose receptor on the HepG2 cellular surface, thus polysaccharides rich in galactose had high anti-tumor cell line activities [25]. ASP-3 polysaccharide from Amomum villosum, which contained more galactose than did ASP-1 and ASP-2, showed the stronger anti-tumor cell line activity [26]. 


\subsection{In Vitro Immunostimulatory Activity of Litchi Polysaccharides}

\subsubsection{Effects of Litchi Polysaccharides on Splenocyte Proliferation in Vitro}

Lymphocyte proliferation is a crucial event in the activation cascade of both cellular and humoral immune responses. Spleen lymphocyte proliferation induced by ConA in vitro was used as a method to evaluate T lymphocyte activity, while that induced by LPS was used to examine B lymphocyte activity [27,28]. The stimulatory effects of LPF and LPD on mouse splenocyte proliferation are presented in Figure 3a. LPF and LPD stimulated the proliferation of mouse splenocyte in a dose-dependent manner. Both LPF and LPD exhibited the highest proliferation indexes (PI) of 20.6\% and $58.45 \%$ at $400 \mu \mathrm{g} / \mathrm{mL}$, respectively. LPD exhibited stronger stimulatory activity toward splenocyte proliferation than LPF at the same concentrations $(p<0.05)$.

Figure 3. Effects of the litchi polysaccharides LPF and LPD on the proliferation index of splenocytes (a), ConA-induced splenocytes (b) and LPS-induced splenocytes (c) at different concentrations $(0,50,100,200$ and $400 \mu \mathrm{g} / \mathrm{mL})$. The proliferation indexes were assessed by the MTT assay and expressed as the mean \pm standard deviation $(n=6)$. Bars labeled with different letters represent a statistical difference at $p<0.05$ among different concentrations of the same sample. $\left({ }^{*}\right) 0.01<p<0.05$ and $(* *) p<0.01$ compared with LPF.

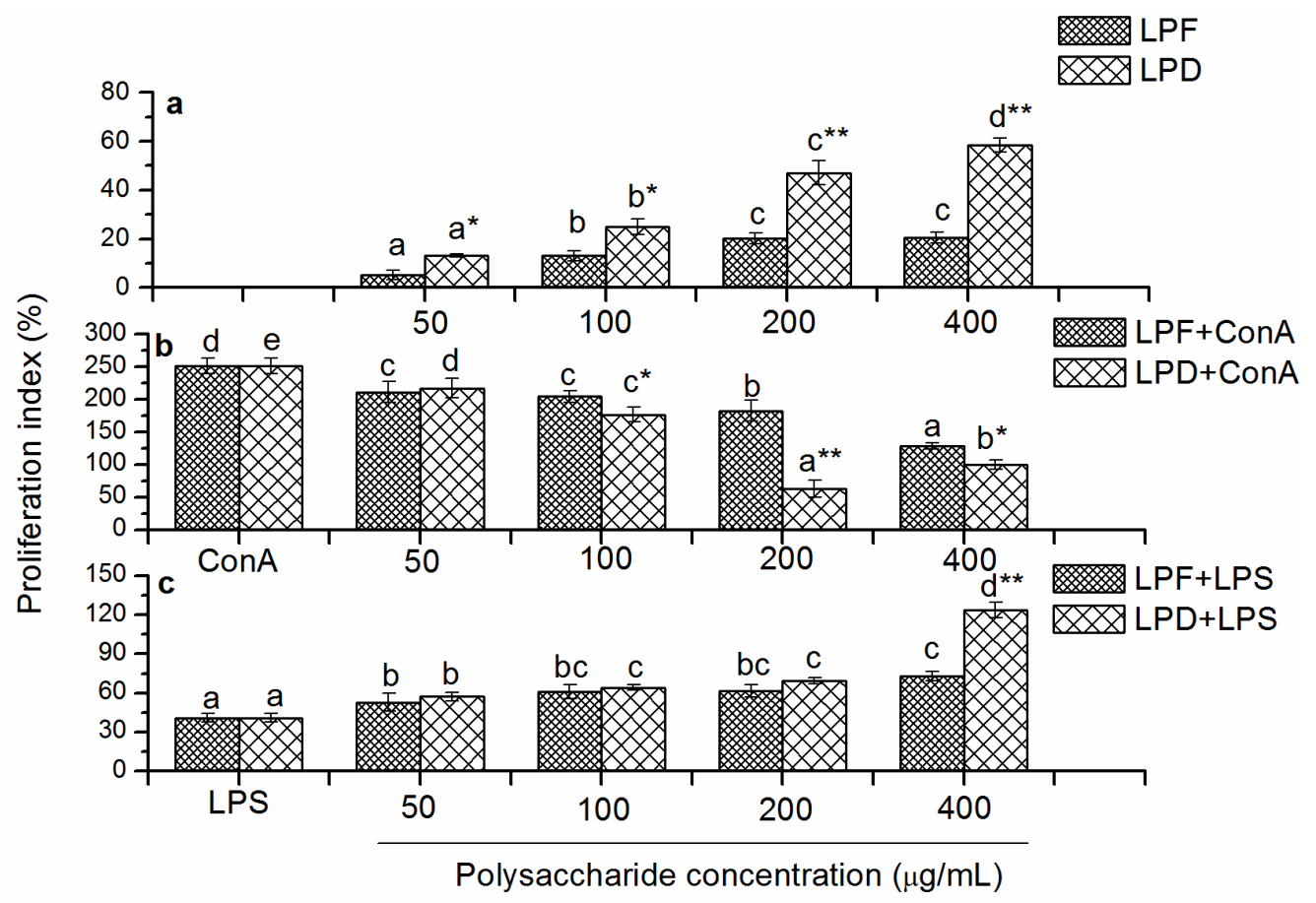

Moreover, both LPF and LPD showed stimulation toward the proliferation of splenocytes with and without LPS (Figure 3a,c). LPD showed stronger proliferative stimulation than LPF. It was indicated that LPD exhibited stronger stimulation in inducing the proliferation of B lymphocyte than LPF. However, addition of litchi polysaccharides attenuated ConA-induced proliferation of splenocytes (Figure $3 b$ ). ConA activated $\mathrm{T}$ lymphocyte by binding to the specific receptor on $\mathrm{T}$ lymphocyte cell membranes [29]. Litchi polysaccharides may compete with ConA for the specific receptor, which resulted in the attenuation of the ConA-induced splenocytes proliferation. Furthermore, the stronger 
inhibition of LPD to ConA-induced splenocytes proliferation gave a clue that LPD may show stronger competition for receptor binding than LPF. The results were similar to another report where polysaccharides from the stems of Ephedra sinica Stapf exhibited inhibitory effects on the proliferation of ConA-stimulated mouse splenocyte [30]. However, our results were inconsistent with Jing's report that the purified litchi polysaccharides LCP50W had the potential of promoting the lymphocyte proliferation along with Con A [15]. This discrepancy could, at least partly, be attributed to the different purity of the tested polysaccharides. Crude, not purified polysaccharides were analyzed in this study. In another word, LPD and LPF were composed of different polysaccharide fractions. Therefore, the bioactivity of these crude polysaccharides should be a combined effect of all the fractions. And some fractions unavoidably had different activity from the others.

To date, the effects of polysaccharides from different materials on lymphocyte proliferation were variously reported. Misgurnus anguillicaudatus polysaccharides activated T cells via the binding of the polysaccharides to receptors specifically expressed on T cells [31]. Polysaccharides from Ganoderma lucidum mediated mouse splenic B cells activation by the induction of Blimp-1, a master regulator capable of triggering the changes of a cascade of gene expression during plasmacytic differentiation [32]. In addition, polysaccharides from evening primrose [27], Trametes robiniophila Murr [33] and Armillaria mellea [34] exhibited stimulating effects on both ConA and LPS-induced lymphocyte proliferation. The mechanism of which polysaccharides exhibited cell specificity in stimulating lymphocyte proliferation is unclear up till now. The monosaccharide composition and structural characteristic of these polysaccharides were deduced to be important influencing factor.

\subsubsection{Effects of Litchi Polysaccharides on NK Cells Cytotoxicity}

The effects of LPF and LPD on the cytotoxicity of NK cells against YAC-1 cells are shown in Figure 4. The percent lysis of target cells was $64.95 \%-78.36 \%$ when the splenocytes were stimulated with $50-400 \mu \mathrm{g} / \mathrm{mL}$ LPF and reached a maximum value at $200 \mu \mathrm{g} / \mathrm{mL}$. The percent lysis of target cells ranged from $74.64 \%$ to $87.72 \%$ when the splenocytes were stimulated with $50-400 \mu \mathrm{g} / \mathrm{mL} \mathrm{LPD}$, with a maximum value at $100 \mu \mathrm{g} / \mathrm{mL}$. Furthermore, compared with LPF, LPD showed stronger stimulation on the NK cells cytotoxicity at the same concentrations in the dose range of $50-400 \mu \mathrm{g} / \mathrm{mL}(p<0.05)$.

\subsubsection{Effects of Litchi Polysaccharides on Phagocytosis of RAW264.7 Mice Macrophages}

The phagocytic activity of RAW264.7 mice macrophages stimulated with LPS or different concentrations of litchi polysaccharides are shown in Figure 5. The phagocytosis indexes induced by LPF were from $26.19 \%$ to $37.34 \%$ at the concentrations from 50 to $400 \mu \mathrm{g} / \mathrm{mL}$ with a maximum value at $200 \mu \mathrm{g} / \mathrm{mL}$. In addition, the phagocytosis indexes induced by LPD were in the range of $27.57 \%-46.12 \%$ at the tested concentration range and exhibited the highest at $200 \mu \mathrm{g} / \mathrm{mL}$. The effect of LPD was significantly better than that of LPF $(p<0.05)$ at $200 \mu \mathrm{g} / \mathrm{mL}$, but no significant difference was observed at other doses. Compared with LPS (40.76\%), $200 \mu \mathrm{g} / \mathrm{mL}$ of LPD (46.12\%) exhibited stronger stimulation on phagocytosis of macrophages $(p<0.01)$. 
Figure 4. Cytotoxicity of NK cells stimulated by litchi polysaccharides LPF and LPD toward target cells. Cytotoxicity of NK cells was assessed by the MTT assay and expressed as the mean \pm standard deviation $(n=6)$. Bars labeled with different letters represent a statistical difference at $p<0.05$ among different concentrations of the same sample. (*) $0.01<p<0.05$ and $(* *) p<0.01$ compared with LPF.

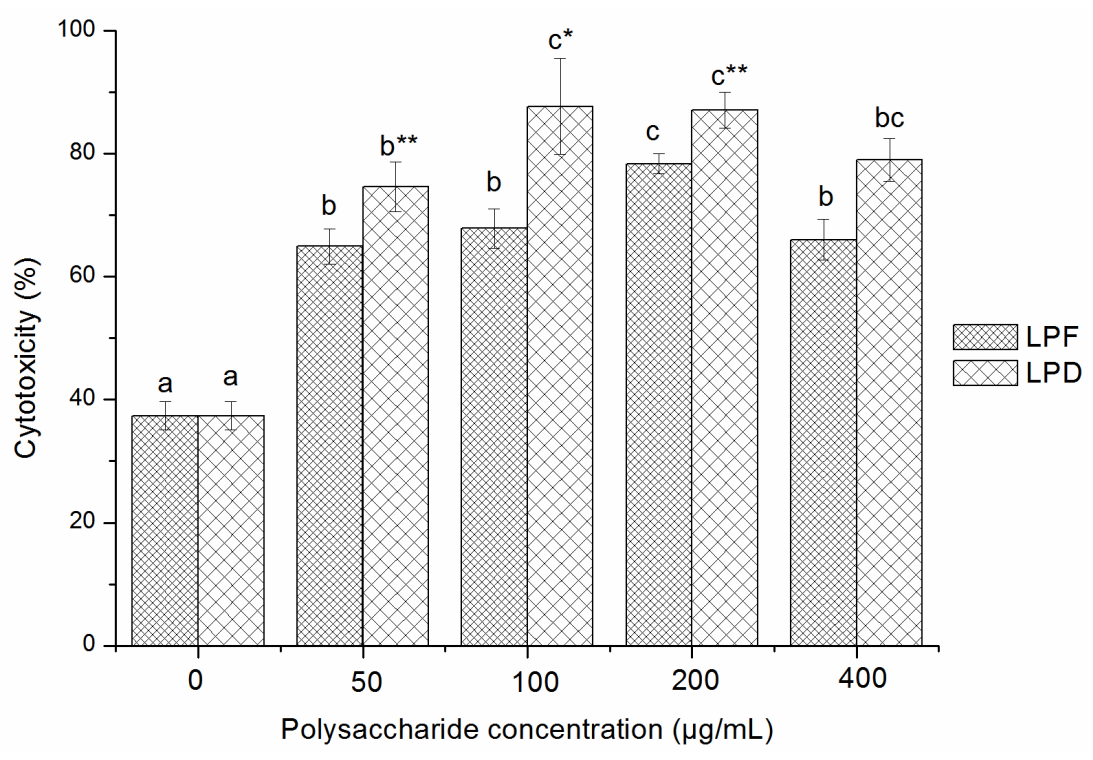

Figure 5. Effects of the litchi polysaccharides LPF and LPD on the phagocytosis of RAW264.7 macrophages. Their phagocytosis indexes were evaluated by measuring the phagocytosis against neutral red and expressed as the mean \pm standard deviation $(n=6)$. Bars labeled with different letters represent a statistical difference at $p<0.05$ among different concentrations of the same sample. $(*) 0.01<p<0.05$ and $(* *) p<0.01$ compared with LPF.

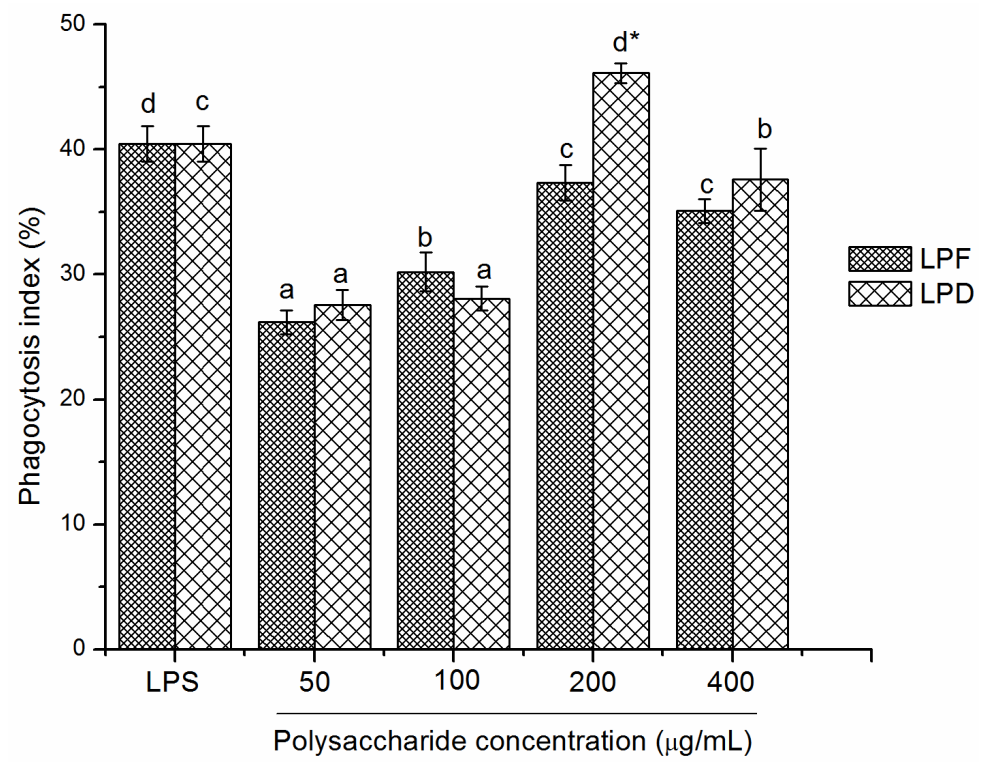

Polysaccharides bind immune cells via membrane receptors, resulting in stimulation of intracellular signaling cascades for immunologic responses. The stimulating activities of polysaccharides triggered 
by the recognition of the cell receptors depend on monosaccharide species and monosaccharide content [35]. Lo et al. reported that arabinose, mannose, xylose and galactose played an important role in the stimulation of macrophage from Lentinula edodes polysaccharides, but not glucose [36]. In addition, mannose played a key role in the immunomodulatory activity of polysaccharide from Longan pulp [28]. The better activities of LPD might be partly related to its monosaccharide proportion and chemical compositions.

\section{Experimental}

\subsection{Materials and Chemicals}

\subsubsection{Chemicals and Reagents}

Standard dextrans, rhamnose (Rha), arabinose (Ara), glucose (Glc), xylose (Xyl), galactose (Gal), mannose (Man), penicillin-streptomycin solution, concanavalin A (ConA), lipopolysaccharide (LPS) and 3-(4,5-dimethylthiazol-2-yl)-2,5-diphenyltetrazolium bromide (MTT) were purchased from Sigma Chemical Co. (St. Louis, MO, USA). RPMI-1640 medium, new bovine calf serum and Hank's balanced salt solution (HBSS) were purchased from Gibco Life Technologies (Grand Island, NY, USA). Other regents were analytical grade.

\subsubsection{Cells and Animals}

Human hepatocellular carcinoma cell line, HepG2; Human uterine cervix carcinoma cell line, Hela; Human lung adenocarcinoma epithelial cell line, A549; YAC-1 mice lymphoma cell line and RAW264.7 mice macrophage cell line were purchased from the Experimental Animal Laboratory of Sun Yat-Sen University (Guangzhou, China). Cells were cultured in RPMI-1640 medium containing $10 \%$ fetal calf serum, $100 \mathrm{U} / \mathrm{mL}$ penicillin and $100 \mu \mathrm{g} / \mathrm{mL}$ streptomycin at $37^{\circ} \mathrm{C}$ and $5 \% \mathrm{CO}_{2}$.

BALB/c mice (male, $20.0 \pm 2.0 \mathrm{~g}$ ), 6-8 w old were provided by the Experimental Animal Laboratory of Sun Yat-Sen University. The mice were acclimatized for $1 \mathrm{w}$ before being used for the study. All the treatments to animals were performed in accordance with the Guide for the Care and Use of Laboratory Animals.

\subsubsection{Preparation of Litchi Fruit}

Fresh fruits of litchi (cv. Gui-wei) were offered by Pomology Research Institute of Guangdong Academy of Agricultural Sciences (Guangzhou, China). Ripened fruits were selected based on their uniform size and lack of visual defects. Some of the litchi fruits were dried by intermittent hot air drying with $2.0 \mathrm{~m} / \mathrm{s}$ flow velocity at $70{ }^{\circ} \mathrm{C}$ for $72 \mathrm{~h}$. The intermittent time was $12 \mathrm{~h}$ for rewetting, and $12 \mathrm{~h}$ for drying time. Dried litchis were peeled and the pulp portion was kept in sealed polyethylene bags at $-20{ }^{\circ} \mathrm{C}$ for further use. The leftover litchi was used as the fresh fruit for the polysaccharide extraction. 


\subsection{Preparation of Crude Litchi Pulp Polysaccharides}

Fresh and dried pulp were cut into small pieces and soaked in $80 \%$ ethanol (final concentration in the system) at $4{ }^{\circ} \mathrm{C}$ for $24 \mathrm{~h}$, to remove the pigments, monosaccharides and oligosaccharides. After filtration through a Whatman No. 1 paper, the residues were homogenized and then extracted twice with distilled water $(1: 20, \mathrm{~g} / \mathrm{mL})$ at $85^{\circ} \mathrm{C}$ for $4 \mathrm{~h}$. The water extracts were filtered, and concentrated to one-fifth of the initial volume in a vacuum evaporator (Eyela, Tokyo, Japan) at $55^{\circ} \mathrm{C}$. The proteins in the extracts were removed using the Sevag reagent [37], and then the polysaccharides were precipitated with four volumes of absolute ethanol for $24 \mathrm{~h}$ at $4{ }^{\circ} \mathrm{C}$. The precipitates were collected by centrifugation at $3000 \mathrm{~g}$ for $20 \mathrm{~min}$, and washed successively with acetone and petroleum ether. Then the precipitates were lyophilized to obtain fresh and dried litchi pulp polysaccharides, named as LPF and LPD, respectively. The litchi polysaccharides were kept in desiccator at room temperature for further use.

\subsection{Preliminary Characterization of Litchi Polysaccharides}

\subsubsection{Analysis of the Chemical Characteristics of Litchi Polysaccharides}

Neutral sugar content was determined by the phenol-sulfuric method using glucose as the standard [38]. The protein content was measured according to Bradford's method with a standard curve using bovine serum albumin (BSA) [39]. The uronic acid content was determined by the $m$-hydroxydiphenyl method with D-glucuronic acid as the standard [40].

The monosaccharide composition of the litchi polysaccharides were determined by GC-MS. Briefly, polysaccharide samples $(40 \mathrm{mg})$ were dissolved in $2 \mathrm{~mol} / \mathrm{L} \mathrm{H}_{2} \mathrm{SO}_{4}(10 \mathrm{~mL})$ and hydrolyzed at $100{ }^{\circ} \mathrm{C}$ for $6 \mathrm{~h}$. After neutralizing the residual acid with $\mathrm{BaCO}_{3}$, the hydrolysate was filtered through $0.2 \mu \mathrm{m}$ syringe filters (Whatman, Sanford, ME, UK) and dried under a stream of $\mathrm{N}_{2}$, then dissolved in pyridine $(5 \mathrm{~mL})$ with hydroxylamine $(70 \mathrm{mg})$ at $90{ }^{\circ} \mathrm{C}$ for $30 \mathrm{~min}$. The samples were cooled and acetic anhydride $(1 \mathrm{~mL})$ was added and the mixture was incubated at $90{ }^{\circ} \mathrm{C}$ for $30 \mathrm{~min}$. The acetylated hydrolysate was extracted by trichloromethane, following by evaporation under a stream of $\mathrm{N}_{2}$. The final product was analyzed by GC-MS, using an Agilent $6890 \mathrm{GC}$ instrument (Agilent Technologies Co., Ltd., Colorado Springs, CO, USA) equipped with a DB-1 column and an Agilent 5973 MS detector. Six monosaccharides (arabinose, mannose, rhamnose, galactose, xylose, and glucose) were used as the external standards to identify the composition of the polysaccharides.

\subsubsection{Determination of Molecular Weights of Litchi Polysaccharides}

The average molecular weights of the litchi polysaccharides were determined by gel permeation chromatography (GPC), which was performed on a Sephacryl S-300HR column $(1.6 \times 70 \mathrm{~cm})$. Standard dextran including T-4 (molecular mass, $\left.4 \times 10^{3} \mathrm{Da}\right)$, T-10 $\left(1 \times 10^{4} \mathrm{Da}\right)$, T-40 $\left(4 \times 10^{4} \mathrm{Da}\right)$, T-70 $\left(7 \times 10^{4} \mathrm{Da}\right)$, T-500 $\left(5 \times 10^{5} \mathrm{Da}\right)$, and T-2000 $\left(2 \times 10^{6} \mathrm{Da}\right)$ were used as molecular mass markers. 


\subsubsection{UV and IR Spectra Analysis}

$\beta$-Elimination reaction: The samples were dissolved in distilled water and forced through a $0.45 \mu \mathrm{m}$ filter membrane to obtain a $1 \mathrm{mg} / \mathrm{mL}$ polysaccharide solution. The solution was mixed with an equal volume of distilled water or $0.4 \mathrm{~mol} / \mathrm{L} \mathrm{NaOH}$. After $1.5 \mathrm{~h}$ incubation at $45^{\circ} \mathrm{C}$, the mixture was then scanned in the wavelength range of 190-400 nm using a UV spectrophotometer (UV 1800, Shimadzu, Kyoto, Japan).

Infrared spectral: The IR spectra of the polysaccharides were determined using a Fourier-transform infrared spectrophotometer (FTIR) (Nexus 5DXC FT-IR, Thermo Nicolet, Austin, TX, USA). The samples were mixed with potassium bromide $(\mathrm{KBr})$ powder and then pressed into $1 \mathrm{~mm}$ thick pellets for FTIR measurement in the frequency range of 4,000-400 $\mathrm{cm}^{-1}$.

\subsection{In Vitro Inhibition Assay of Tumor Cells Proliferation of Litchi Polysaccharides}

\subsubsection{Cytotoxicity Assay of Tumor Cells}

The cytotoxicity of litchi polysaccharides was measured by using a methylene blue assay method [41]. Briefly, when each cancer cell line was adjusted to an appropriate level, $100 \mu \mathrm{L}$ of a cell suspension (HepG2: $4 \times 10^{4}$ cells $/ \mathrm{mL}$; Hela: $4 \times 10^{4}$ cells $/ \mathrm{mL}$; A549: $6 \times 10^{4}$ cells $/ \mathrm{mL}$ ), was plated in 96-well plates. Cells were left for $6 \mathrm{~h}$ to attach, and medium was replaced with litchi polysaccharides which were dissolved in RPMI-1640 medium, and cells were kept at $37{ }^{\circ} \mathrm{C}$ in $5 \% \mathrm{CO}_{2}$ for another $24 \mathrm{~h}$. Then, the medium was aspirated and each well was gently rinsed with phosphate-buffered saline (PBS) twice. Cells were stained and fixed by adding $50 \mu \mathrm{L}$ methylene blue solution (HBSS $+1.25 \%$ glutaraldehyde $+0.6 \%$ methylene blue) to each well. After $1 \mathrm{~h}$ incubation, plates were rinsed by gently submerging in distilled water six times. Plates were drained and air-dried before addition of $100 \mu \mathrm{L}$ elution solution $(50 \%$ ethanol $+49 \%$ PBS $+1 \%$ acetic acid) to each well and homogenized for $15 \mathrm{~min}$ to fully dissolve the stained materials. The plates were read using a microplate reader at $570 \mathrm{~nm}$.

\subsubsection{Inhibition Assay of Tumor Cells Proliferation}

The inhibition effects of the polysaccharides on the growth of tumor cells were evaluated by a methylene blue method described previously. HepG2, Hela and A549 cells were plated at the density of $2 \times 10^{4}$ cells $/ \mathrm{mL}, 2 \times 10^{4}$ cells $/ \mathrm{mL}$ and $4 \times 10^{4}$ cells $/ \mathrm{mL}$, respectively, in 96-well plates and left for $6 \mathrm{~h}$ to attach. Then, litchi polysaccharides containing medium was added to replace the old medium at final concentrations of 50, 150, 300, 450, 600, and $750 \mu \mathrm{g} / \mathrm{mL}$. After $72 \mathrm{~h}$ of incubation, cells were stained with methylene blue solution for $1 \mathrm{~h}$. Cells were then rinsed with water and dried. Methylene blue stain was eluted with the elution solution by agitating plates at room temperature for $1 \mathrm{~h}$. The absorbance was measured at $570 \mathrm{~nm}$ by a microplate reader (Thermo Labsystems, Helsinki, Finland). The inhibition rate $(\%)$ was calculated as: $(1-$ ODs/ODc $) \times 100$, where ODs and ODc represented the OD value of the samples and control group, respectively. 


\subsection{In Vitro Immunostimulatory Activity Assay of Litchi Polysaccharides}

\subsubsection{Determination of Mouse Splenocyte Proliferation}

The splenocyte proliferation assay was performed according to a reported method [28]. Briefly, the male BALB/c mice were sacrificed by cervical dislocation and their spleens were removed aseptically and minced in PBS. The splenic cells were obtained through sterilized meshes (200 mesh) at room temperature. After lysing red blood cells with hemolytic Gey's solution, the remaining cells were washed twice and resuspended in RPMI 1640 complete medium. The overall cell viability was greater than $95 \%$ and was determined using the trypan-blue dye exclusion technique.

One hundred microliters of splenic cell suspension was seeded in 96-well plates at $5 \times 10^{6}$ cells $/ \mathrm{mL}$ with litchi polysaccharides containing medium at final concentrations of $0,50,100,200$ and $400 \mu \mathrm{g} / \mathrm{mL}$. The cells were cultured at $37{ }^{\circ} \mathrm{C}$ and $5 \% \mathrm{CO}_{2}$ with or without $5 \mu \mathrm{g} / \mathrm{mL}$ ConA or $10 \mu \mathrm{g} / \mathrm{mL}$ LPS for $68 \mathrm{~h}$. Then, MTT $(20 \mu \mathrm{L}, 5 \mathrm{mg} / \mathrm{mL})$ was added to each well. After a further $4 \mathrm{~h}$ of incubation, $100 \mu \mathrm{L}$ acidified isopropyl alcohol was added to dissolve the formazan crystals for $12 \mathrm{~h}$ at $37{ }^{\circ} \mathrm{C}$. The plates were finally read at $570 \mathrm{~nm}$ in a microplate reader. The proliferation indexes (\%) of splenocyte were calculated as: $(\mathrm{ODs} / \mathrm{ODc}-1) \times 100$, where ODs and ODc represented the OD value of the samples and control group, respectively.

\subsubsection{Cytotoxicity Assay of Natural Killer Cells}

Splenocytes were prepared as the effector cells for a splenic natural killer (NK) activity assay as described by Yi et al. [42]. The splenocytes were plated into 96-well plates at a density of $1 \times 10^{7}$ cells $/ \mathrm{mL}$ per well in a $50 \mu \mathrm{L}$ volume, and stimulated with $40 \mu \mathrm{L}$ different concentrations of litchi polysaccharides (ultimate concentration: $0,50,100,200,400 \mu \mathrm{g} / \mathrm{mL}$ ) for $24 \mathrm{~h}$, with twelve replicate wells employed for each concentration. Then, YAC-1 cells $\left(10 \mu \mathrm{L}, 1 \times 10^{6}\right.$ cells $\left./ \mathrm{mL}\right)$ were added into six wells as the experimental group and complete medium was placed in the other six wells of the twelve replicate wells as the effector control. At the same time, complete medium $(100 \mu \mathrm{L})$, containing YAC-1 cells $\left(10 \mu \mathrm{L}, 1 \times 10^{6}\right.$ cells $\left./ \mathrm{mL}\right)$ was added into empty wells as the target control. The plates were incubated for $4 \mathrm{~h}$, followed by another $4 \mathrm{~h}$ with MTT $(20 \mu \mathrm{L}, 5 \mathrm{mg} / \mathrm{mL})$. Then, acidified isopropyl alcohol $(100 \mu \mathrm{L})$ was added to each well followed by a $12 \mathrm{~h}$ incubation. The absorbance was measured at $570 \mathrm{~nm}$ using a microplate reader. Cytotoxicity of NK cell was expressed as percent lysis of target cells: $\left[\mathrm{OD}_{\mathrm{T}}-(\mathrm{OD} \exp -\mathrm{ODE})\right] / \mathrm{OD}_{\mathrm{T}} \times 100$, where $\mathrm{OD}_{\mathrm{T}}, \mathrm{OD} \exp$ and $\mathrm{OD}_{\mathrm{E}}$ represented the OD value of the target control, experimental group and effector control group, respectively.

\subsubsection{Assay of Phagocytosis of RAW264.7 Macrophages}

RAW264.7 macrophages $\left(1 \times 10^{5}\right.$ cells/well $)$ were seeded in 96-well plates and allowed to adhere for $6 \mathrm{~h}$. After removing the growth media from each well, different concentrations of litchi polysaccharides $(0,50,100,200,400 \mu \mathrm{g} / \mathrm{mL})$ prepared with culture medium, were added to each well in $100 \mu \mathrm{L}$ and $10 \mu \mathrm{g} / \mathrm{mL}$ LPS was used as a positive control. After $24 \mathrm{~h}$ of incubation, the supernatant was removed and each well was gently rinsed with PBS twice. One hundred microliters of $0.075 \%$ neutral red solution was added to each well and the plates were cultured for a further $4 \mathrm{~h}$. After washing 
out unphagocytized neutral red with PBS, cell lysis buffer $(100 \mu \mathrm{L}$, acetic acid/ethanol $=1: 1, \mathrm{~mL} / \mathrm{mL})$ was added to each well for $12 \mathrm{~h}$. The OD value of each well was measured at $570 \mathrm{~nm}$. The phagocytosis index $(\%)$ was calculated as: $\left(\mathrm{OD}_{\mathrm{S}} / \mathrm{OD}_{\mathrm{C}}-1\right) \times 100$, where $\mathrm{OD}_{\mathrm{S}}$ and $\mathrm{OD}_{\mathrm{C}}$ represented the OD values of the stimulated group and control group, respectively.

\subsection{Statistical Analysis}

Data were expressed as the mean \pm standard deviations (SD). The significance of the difference was evaluated with one-way ANOVA followed by the Student-Newman-Keuls test using SPSS 19.0 software and a $p$-value of 0.05 was used as the threshold for significance. The statistically significant differences between the two groups were evaluated with an independent-sample $T$-test.

\section{Conclusions}

The drying process yielded polysaccharides with more uronic acid and protein as well as lower overall molecular weight than those obtained from fresh litchi. The monosaccharide molar ratio of LPF and LPD were significantly different. LPD showed relatively higher cytotoxic activity against three different tumor cell lines and in vitro immunomodulatory activity than LPF. Therefore, hot air drying can effectively change the chemical composition of litchi polysaccharides and improve their bioactivity. This finding supports the application of dried litchi pulp as a Traditional Chinese Medicine. Furthermore, the structural and bioactivity differences observed for polysaccharides obtained from dried litchi using different methods is an ongoing topic of research.

\section{Acknowledgments}

This work was supported by a Joint Fund of the NSFC and Guangdong Provincial Government (U1301211), a Special Prophase Project of The National Basic Research Program of China (2012CB722904), the International Science \& Technology Cooperation Program of China (2012DFA31400) and the National "948” project (2012-S18).

\section{Author Contributions}

F. Huang and M.W. Zhang conceived of this study and designed the experiments. R.F. Zhang, F. Huang and Y. Yang, performed the experiments. All the authors analyzed the data and discussed the results. F. Huang and R.F. Zhang drafted the manuscript with the help of M.W. Zhang. All the authors have read and approved the final manuscript.

\section{Conflicts of Interest}

The authors declare no conflict of interest.

\section{References}

1. Kong, F.; Zhang, M.; Liao, S.; Yu, S.; Chi, J.; Wei, Z. Antioxidant activity of polysaccharide-enriched fractions extracted from pulp tissue of Litchi Chinensis sonn. Molecules 2010, 15, 2152-2165. 
2. Jiang, G.; Lin, S.; Wen, L.; Jiang, Y.; Zhao, M.; Chen, F.; Prasad, K.N.; Duan, X.; Yang, B. Identification of a novel phenolic compound in litchi (Litchi chinensis Sonn.) pericarp and bioactivity evaluation. Food Chem. 2013, 136, 563-568.

3. Zhou, Y.; Wang, H.; Yang, R.; Huang, H.; Sun, Y.; Shen, Y.; Lei, H.; Gao, H. Effects of Litchi chinensis fruit isolates on prostaglandin $\mathrm{E}(2)$ and nitric oxide production in $\mathrm{J} 774$ murine macrophage cells. BMC Complement. Altern. Med. 2012, 12, doi:10.1186/1472-6882-12-12.

4. Wang, X.; Wei, Y.; Yuan, S.; Liu, G.; Zhang, Y.L.J.; Wang, W. Potential anticancer activity of litchi fruit pericarp extract against hepatocellular carcinoma in vitro and in vivo. Cancer Lett. 2006, 239, 144-150.

5. Bhoopat, L.; Srichairatanakool, S.; Kanjanapothi, D.; Taesotikul, T.; Thananchai, H.; Bhoopat, T. Hepatoprotective effects of lychee (Litchi chinensis Sonn.): A combination of antioxidant and anti-apoptotic activities. J. Ethnopharmacol. 2011, 136, 55-66.

6. Zhao, M.; Yang, B.; Wang, J.; Liu, Y.; Yu, L.; Jiang, Y. Immunomodulatory and anticancer activities of flavonoids extracted from litchi (Litchi chinensis Sonn.) pericarp. Int. Immunopharmacol. 2007, 7, 162-166.

7. Hu, X.Q.; Huang, Y.Y.; Dong, Q.F.; Song, L.Y.; Yuan, F.; Yu, R.M. Structure characterization and antioxidant activity of a novel polysaccharide isolated from pulp tissues of Litchi chinensis. J. Agric. Food Chem. 2011, 59, 11548-11552.

8. Garau, M.C.; Simal, S.; Rosselló, C.; Femenia, A. Effect of air-drying temperature on physico-chemical properties of dietary fibre and antioxidant capacity of orange (Citrus aurantium v. Canoneta) by-products. Food Chem. 2007, 104, 1014-1024.

9. Chang, C.-H.; Lin, H.-Y.; Chang, C.-Y.; Liu, Y.-C. Comparisons on the antioxidant properties of fresh, freeze-dried and hot-air-dried tomatoes. J. Food Eng. 2006, 77, 478-485.

10. Ferreira, D.; Barros, A.; Coimbra, M.; Delgadillo, I. Use of FT-IR spectroscopy to follow the effect of processing in cell wall polysaccharide extracts of a sun-dried pear. Carbohydr. Polym. 2001, 45, 175-182.

11. Ali Asgar, M. Structural features of pectins from fresh and sun-dried Japanese persimmon fruit. Food Chem. 2004, 87, 247-251.

12. Thetsrimuang, C.; Khammuang, S.; Chiablaem, K.; Srisomsap, C.; Sarnthima, R. Antioxidant properties and cytotoxicity of crude polysaccharides from Lentinus polychrous Lév. Food Chem. 2011, 128, 634-639.

13. Ma, L.; Chen, H.; Zhu, W.; Wang, Z. Effect of different drying methods on physicochemical properties and antioxidant activities of polysaccharides extracted from mushroom Inonotus obliquus. Food Res. Int. 2013, 50, 2152-2165.

14. Kong, F.-L.; Zhang, M.-W.; Kuang, R.-B.; Yu, S.-J.; Chi, J.-W.; Wei, Z.-C. Antioxidant activities of different fractions of polysaccharide purified from pulp tissue of litchi (Litchi chinensis Sonn.). Carbohydr. Polym. 2010, 81, 612-616.

15. Jing, Y.; Huang, L.; Lv, W.; Tong, H.; Song, L.; Hu, X.; Yu, R. Structure Characterization of a Novel Polysaccharide from Pulp Tissues of Litchi chinensis and its Immunomodulatory Activity. J. Agric. Food Chem. 2013, 62, 902-911. 
16. Ducel, V.; Saulnier, P.; Richard, J.; Boury, F. Plant protein-polysaccharide interactions in solutions: Application of soft particle analysis and light scattering measurements. Colloids Surf. 2005, 41, 95-102.

17. Satitmanwiwat, S.; Ratanakhanokchai, K.; Laohakunjit, N.; Chao, L.K.; Chen, S.T.; Pason, P.; Tachaapaikoon, C.; Kyu, K.L. Improved purity and immunostimulatory activity of beta-(1->3) (1->6)-glucan from Pleurotus sajor-caju using cell wall-degrading enzymes. J. Agric. Food Chem. 2012, 60, 5423-5430.

18. Zhang, N.; Chen, H.; Ma, L.; Zhang, Y. Physical modifications of polysaccharide from Inonotus obliquus and the antioxidant properties. Int. J. Biol. Macromol. 2013, 54, 209-215.

19. Mirhosseini, H.; Amid, B.T.; Cheong, K.W. Effect of different drying methods on chemical and molecular structure of heteropolysaccharide-protein gum from durian seed. Food Hydrocolloids 2013, 31, 210-219.

20. Asgar, M.A.; Yamauchi, R.; Kato, K. Modification of pectin in Japanese persimmon fruit during the sun-drying process. Food Chem. 2003, 81, 555-560.

21. Doublier, J.-L.; Garnier, C.; Renard, D.; Sanchez, C. Protein-polysaccharide interactions. Curr. Opin. Colloid Interface Sci. 2000, 5, 202-214.

22. Zhang, W. Biochemical Technology of Carbohydrate Complexes; Zhejiang University Press: Hangzhou, China, 1994.

23. Tian, L.; Zhao, Y.; Guo, C.; Yang, X. A comparative study on the antioxidant activities of an acidic polysaccharide and various solvent extracts derived from herbal Houttuynia cordata. Carbohydr. Polym. 2011, 83, 537-544.

24. Xin, T.; Zhang, F.; Jiang, Q.; Chen, C.; Huang, D.; Lv, Y.; Shen, W.; Jin, Y. Purification and antitumor activity of two acidic polysaccharides from the roots of Polygala tenuifolia. Carbohydr. Polym. 2012, 90, 1671-1676.

25. Ouchi, T.; Matsumoto, M.; Ihara, K.; Ohya, Y. Synthesis and cytotoxic activity of oxidized galactomannan/ADR conjugate. J. Macromol. Sci. Part A Pure Appl. Chem. 1997, 34, 975-989.

26. Zhang, D.; Li, S.; Xiong, Q.; Jiang, C.; Lai, X. Extraction, characterization and biological activities of polysaccharides from Amomum villosum. Carbohydr. Polym. 2013, 95, 114-122.

27. Zeng, G.; Ju, Y.; Shen, H.; Zhou, N.; Huang, L. Immunopontentiating activities of the purified polysaccharide from evening primrose in $\mathrm{H} 22$ tumor-bearing mice. Int. J. Biol Macromol. 2013, $52,280-285$.

28. Yi, Y.; Liao, S.T.; Zhang, M.W.; Shi, J.; Zhang, R.F.; Deng, Y.Y.; Wei, Z.C. Physicochemical characteristics and immunomodulatory activities of three polysaccharide-protein complexes of longan pulp. Molecules 2011, 16, 6148-6164.

29. Iribe, H.; Koga, T. Augmentation of the proliferative response of thymocytes to phytohemagglutinin by the muramyl dipeptide. Cell Immunol. 1984, 88, 9-15.

30. Kuang, H.; Xia, Y.; Yang, B.; Wang, Q.; Wang, Y. Screening and comparison of the immunosuppressive activities of polysaccharides from the stems of Ephedra sinica Stapf. Carbohydr. Polym. 2011, 83, 787-795.

31. Zhang, C.; Huang, K. Characteristic immunostimulation by MAP, a polysaccharide isolated from the mucus of the loach, Misgurnus anguillicaudatus. Carbohydr. Polym. 2005, 59, 75-82. 
32. Lin, K.-I.; Kao, Y.-Y.; Kuo, H.-K.; Yang, W.-B.; Chou, A.; Lin, H.-H.; Alice, L.Y.; Wong, C.-H. Reishi polysaccharides induce immunoglobulin production through the TLR4/TLR2-mediated induction of transcription factor Blimp-1. J. Biol. Chem. 2006, 281, 24111-24123.

33. Sun, Y.; Sun, T.; Wang, F.; Zhang, J.; Li, C.; Chen, X.; Li, Q.; Sun, S. A polysaccharide from the fungi of Huaier exhibits anti-tumor potential and immunomodulatory effects. Carbohydr. Polym. 2013, 92, 577-582.

34. Sun, Y.; Liang, H.; Zhang, X.; Tong, H.; Liu, J. Structural elucidation and immunological activity of a polysaccharide from the fruiting body of Armillaria mellea. Bioresour. Technol. 2009, 100, 1860-1863.

35. Kralovec, J.; Metera, K.; Kumar, J.; Watson, L.; Girouard, G.; Guan, Y.; Carr, R.; Barrow, C.; Ewart, H. Immunostimulatory principles from Chlorella $\mathrm{p}$ yrenoidosa-Part 1: Isolation and biological assessment in vitro. Phytomedicine 2007, 14, 57-64.

36. Lo, T.C.; Jiang, Y.H.; Chao, A.L.; Chang, C.A. Use of statistical methods to find the polysaccharide structural characteristics and the relationships between monosaccharide composition ratio and macrophage stimulatory activity of regionally different strains of Lentinula edodes. Anal. Chim. Acta 2007, 584, 50-56.

37. Sevag, M.; Lackman, D.B.; Smolens, J. The isolation of the components of streptococcal nucleoproteins in serologically active form. J. Biol. Chem. 1938, 1938, 425-436.

38. Dubois, M.; Gilles, K.A.; Hamilton, J.K.; Rebers, P.; Smith, F. Colorimetric method for determination of sugars and related substances. Anal. Chem. 1956, 3, 350-356.

39. Bradford, M.M. A rapid and sensitive method for the quantitation of microgram quantities of protein utilizing the principle of protein-dye binding. Anal. Biochem. 1976, 72, 248-254.

40. Blumenkrantz, N.; Asboe-Hansen, G. New method for quantitative determination of uronic acids. Anal. Biochem. 1973, 54, 484-489.

41. Felice, D.L.; Sun, J.; Liu, R.H. A modified methylene blue assay for accurate cell counting. J. Funct. Foods 2009, 1, 109-118.

42. Yi, Y.; Zhang, M.-W.; Liao, S.-T.; Zhang, R.-F.; Deng, Y.-Y.; Wei, Z.-C.; Tang, X.-J.; Zhang, Y. Structural features and immunomodulatory activities of polysaccharides of longan pulp. Carbohydr. Polym. 2012, 87, 636-643.

Sample Availability: Samples of polysaccharides are available from the authors.

(C) 2014 by the authors; licensee MDPI, Basel, Switzerland. This article is an open access article distributed under the terms and conditions of the Creative Commons Attribution license (http://creativecommons.org/licenses/by/3.0/). 